\title{
Divergent EME Responses to Global and Domestic Monetary Policy Shocks
}

\author{
Woon Gyu Choi*, Byongju Lee**, \\ Taesu Kang ${ }^{* * *}$, Geun-Young Kim****
}

The views expressed herein are those of the authors and do not necessarily reflect the official views of the Bank of Korea and IMF. When reporting or citing this paper, the authors' names should always be explicitly stated.

\footnotetext{
* Senior Economist, IMF Institute, E-mail: wchoi@imf.org.

** Economist, Economic Research Institute, The Bank of Korea, Tel: +82-2-759-5435, E-mail: brian.lee@bok.or.kr. *** Senior Economist, Research Department, The Bank of Korea, Tel: +82-2-759-4208, E-mail: tskang@bok.or.kr. **** Head, Research Department, The Bank of Korea, Tel: +82-2-759-5280, E-mail: kgy3104@bok.or.kr.

This paper is a revision of a previous work titled "U.S. Monetary Policy Normalization and EME Policy Mix from a Global Liquidity Perspective." The authors are grateful to participants of NBER East Asia Seminar on Economics in 2014 and the international conference on financial cycles, system risk, interconnectedness, and policy options for resilience in 2016 for helpful comments.
} 


\section{Contents}

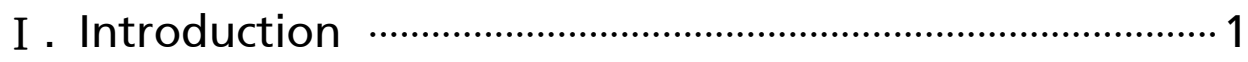

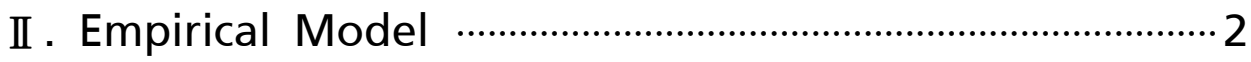

III. EME Responses to U.S. and Domestic Monetary Tightening ………………………………………………………… 5

IV. Divergent EME Responses to U.S. Monetary Policy Shocks 12

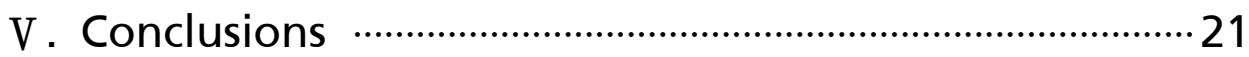

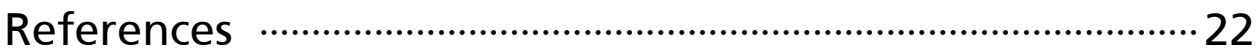

Appendix 


\section{Divergent EME Responses to Global and Domestic Monetary Policy Shocks}

We assess the effect of tighter monetary policy in the U.S. and emerging market economies (EMEs) on EMEs using a panel factor-augmented VAR model. We find that a U.S. policy rate hike outstrips an equivalent domestic rate hike in its impacts on EMEs. In addition, EMEs show divergent policy responses and their macro-financial responses differ depending upon their economic fundamentals in the face of tighter U.S. policy. In particular, we find that high-inflation than low-inflation EMEs are more susceptible to the shock stemming from a U.S. federal funds rate hike.

Keywords: Global liquidity, Monetary transmission, Divergent responses, Panel factor-augmented VAR

JEL Classification: F32, F42 


\section{I . Introduction}

The macroeconomic landscape of emerging market economies (EMEs) could be shaped by global business cycles, global liquidity cycles, domestic business cycles, and domestic liquidity cycles. This paper attempts to analyze the influence of global and domestic liquidity cycles, focusing on how U.S. and domestic policy rates affect macroeconomic outcomes and capital inflows in EMEs.

We analyze how growth and inflation in EMEs react to a U.S. federal funds rate hike. Considering that the U.S. policy rate had stayed at the zero lower bound for a significant period after the Global Financial Crisis (GFC), we utilize a factor model to measure the policy stance even with the policy rate at its zero lower bound and derive three liquidity momenta associated with global financial cycles. The derivation and characteristics of these series are covered in Choi, Kang, Kim, and Lee (2014), which identifies the three global liquidity momenta from a VAR with sign restrictions based on macro-financial variables of advanced economies, including the U.S. federal funds rate and monetary base. We apply a factor-augmented vector autoregressive (FAVAR) model to EME panel data.

This approach allows U.S. to control the other elements of global liquidity cycles and idiosyncratic characteristics of each EME. We look into the effects on growth, inflation, capital inflows, stock prices, exchange rates, current account, domestic policy rates and foreign reserves. The empirical approach is also employed to gauge the effects of domestic policy tightening in EMEs.

Capital flows into EMEs are an important transmission channel of global liquidity cycles, as examined by Rey (2015); Broner, Didier, Erce and Schmulker (2013); Alberola, Erce and Serena (2016); Kim and Shin (2015); and Morgan (2011). We analyze four components of capital inflows: bond investments, equity investments, foreign direct investments and other investments.

The second part of this paper explores how divergent EMEs' sensitivities to global liquidity cycles are associated with their economic fundamentals. Previous studies have looked into differences in region, industrial structure or 
exchange rate regime to figure out the source of divergent impacts. We group data points of the panel by the level of the relevant variables, such as inflation, real GDP growth, current account or foreign reserves. Then, we evaluate the welfare loss of each group from U.S. monetary tightening and determine the fundamental that most strongly influences the welfare outcome in the event of an external shock. In addition, we carry out a counterfactual exercise to determine whether there exist any welfare gains if the EMEs with vulnerable fundamentals took the domestic shock-absorbing structures of their relatively robust counterparts.

Our three key findings are as follows. First, a U.S. interest rate hike outstrips a domestic interest rate hike on its impacts on EMEs. In particular, a one-percent increase of the federal funds rate reduces the GDP growth of EMEs by a half percent cumulatively for three years, while a one-percent increase in the domestic policy rate of EMEs on average slows down their economies by 0.16 percent. Second, All components of capital inflows to EMEs shrink in response to the U.S. policy rate hike, but only bond investments by foreigners respond significantly to EMEs' own policy rate hike. Third, high-inflation EMEs are more susceptible than low-inflation EMEs in terms of growth and inflation to tighter global liquidity. High-inflation EMEs can achieve some welfare gains if they adopt a domestic economic structure conducive to inflation stability.

The rest of the paper is organized as follows. Section $\mathbb{I}$ presents the FAVAR model used in this paper, and Section III illustrates the effects of U.S. and domestic monetary tightening. Section IV investigates the sources of fragility of EMEs, and Section V concludes.

\section{Empirical Model}

This section briefly explains the empirical model used in this study. The model is introduced in the companion paper, Choi et al. (2014), which offers the characteristics of the model in detail. We assume that there are three global liquidity momenta $\left(F_{t}\right)$, namely, policy-driven liquidity momentum, market-driven 
liquidity momentum and risk averseness momentum.

The three global liquidity momenta are retrieved from financial data $\left(X_{t}\right)$ of the G5 (the United States, Germany, France, Japan and the United Kingdom) using a factor model with sign restrictions. For example, policy-driven liquidity momentum is set to increase the U.S. monetary base. The underlying financial time series used in retrieving factors are policy rates, domestic credit, international claims, lending rate spreads, government bond yields, monetary base, real interest rates, stock prices, and stock volatility.

$$
X_{t}=\Lambda F_{t}+u_{t}
$$

The above equation shows that underlying data $X_{t}$ are explained by factors $F_{t}$ and their idiosyncratic disturbances $\left(u_{t}\right)$, of which the covariance is $\Psi$.

Factors $F_{t}$ are assumed to be exogenous to EMEs in explaining macroeconomic and financial situation $Y_{t}$ as expressed in (2). Note that the factors have contemporaneous effects on EMEs.

$$
\begin{gathered}
Y_{t}=\sum_{i=1}^{k} A_{i} Y_{t-i}+\sum_{i=1}^{l} B_{i} F_{t-i+1}+\varepsilon_{t} \\
F_{t}=\sum_{i=1}^{m} C_{i} F_{t-i}+\nu_{t}
\end{gathered}
$$

The macroeconomic and financial situation of an EME is described by several variables in $Y_{t}$ : real GDP growth, inflation in consumer price index (CPI), current account balance, stock prices, nominal effective exchange rate, and capital inflows. Two policy variables, overnight call rates and foreign reserves, are also included. The countries in the EME panel are Argentina, Brazil, Bulgaria, Chile, Czech Republic, Hungary, India, Indonesia, Israel, Korea, Malaysia, Mexico, Philippines, Poland, Romania, Russia, South Africa, Thailand, and Turkey.

The sample period runs from the second quarter of 1995 to the third quarter of 2014. Real GDP, CPI, capital inflows, foreign reserves and current account are seasonally adjusted and the trend component of the overnight call 
rate is removed by the Hodrick-Prescott filter. Real GDP, inflation, exchange rates and stock prices are measured in the quarter-over-quarter growth rate, and capital inflows, current account and foreign reserves are measured as percentages of the 5-year average of annualized nominal GDP. Components of capital inflows are processed in the same fashion as capital inflows. The sample period goes from the second quarter of 1995 to the third quarter of 2014. Two lags are used for the endogenous variables, and the contemporaneous factor and one-period-lag factor are included in Equation (2). To recover the shock process $\left(\nu_{t}\right)$ in global liquidity momenta, an autoregressive structure with lag order one in equation (2) and (3) is chosen on the basis of the Hannan and Quinn (1979) information criterion.

An increase in the U.S. federal funds rate is applied in vector $X_{t}$ and this in turn feeds into $F_{t}$. The accompanying changes in $F_{t}$ embark the dynamic process of EMEs' domestic economies, which is expressed in equation (2). For the first step, we assume multivariate normality of $X_{t}$ and $F_{t}$, as follows:

$$
\left(\begin{array}{l}
X_{t} \\
F_{t}
\end{array}\right)=N\left[\left(\begin{array}{l}
0 \\
0
\end{array}\right),\left(\begin{array}{ccc}
\Lambda \Lambda^{\prime}+\Psi & \Lambda \\
\Lambda^{\prime} & I
\end{array}\right)\right] .
$$

The conditional distribution $X_{t}$ given $F_{t}$ is also given by

$$
F_{t} \mid X_{t} \sim N\left[\Lambda^{\prime}\left(\Lambda \Lambda^{\prime}+\Psi\right)^{-1} X_{t}, I-\Lambda^{\prime}\left(\Lambda \Lambda^{\prime}+\Psi\right)^{-1} \Lambda^{\prime}\right]
$$

Hence, given the value of $X_{t}$, the expected shock is

$$
E\left(F_{t} \mid X_{t}\right)=\Lambda^{\prime}\left(\Lambda \Lambda^{\prime}+\Psi\right)^{-1} X_{t}
$$

While it is not unlikely that a change in the U.S. policy rate would accompany changes in the market-driven factor and risk averseness factor, we concentrate on the effect of the policy-driven factor extracted from global liquidity. Technically, this approach entails measuring a change in the policy-driven liquidity factor while the other two remain fixed. Using the well-known formula of conditional expectations under the assumption of multivariate normal distribution, we obtained the expected value of the policy-driven factor given 
the other two factors.

We consider two scenarios of adjustment in $X_{t}$. The first scenario supposes a one-percentage-point hike in the federal funds rate, and the second scenario entails a one-percentage-point increase in the U.S. real interest rate in addition to the federal funds rate increase. The second scenario reflects the slow response of U.S. inflation to monetary tightening, as observed in Romer and Romer (2004) and Christiano, Eichenbaum and Evans (1999). The first scenario brings about a shock tantamount to 58 percent of the standard deviation of the policy-driven factor; and the shock of the second scenario corresponds to 87 percent of the standard deviation. We take the second scenario, which incorporates both the real interest rate rise and policy rate hike, as the baseline.

Since we drive factors from the financial and monetary data of five advanced countries, including the U.S., any combination of changes in underlying variables $X_{t}$ is at our disposal for scenario exercises. We deliberately turn off concomitant changes from other advanced countries in consideration of the growing divergence in macroeconomic situations and corresponding monetary stances among leading advanced countries. We nonetheless keep the normal transmission of U.S. monetary policy to the U.S. price level intact after the GFC. In particular, we do not take into account any inflation pressures stemming from structural drifts (for example, perpetual shifts in productivity growth and demography) that would ultimately alter real interest rates.

\section{EME Responses to U.S. and Domestic Monetary Tightening}

\section{Reactions in growth, inflation and policy}

The immediate impact of global liquidity withdrawal is a reversal in net capital flows, which includes a suspension or reversal in capital inflows. Our finding in the first row of Figure 1 confirms this front line impact and accompanying repercussions on exchange rates and stock prices. As the supply of liquidity from foreign sources shrinks in the domestic financial markets, it 
Figure 1: EME Responses to a U.S. Federal Funds Rate Hike
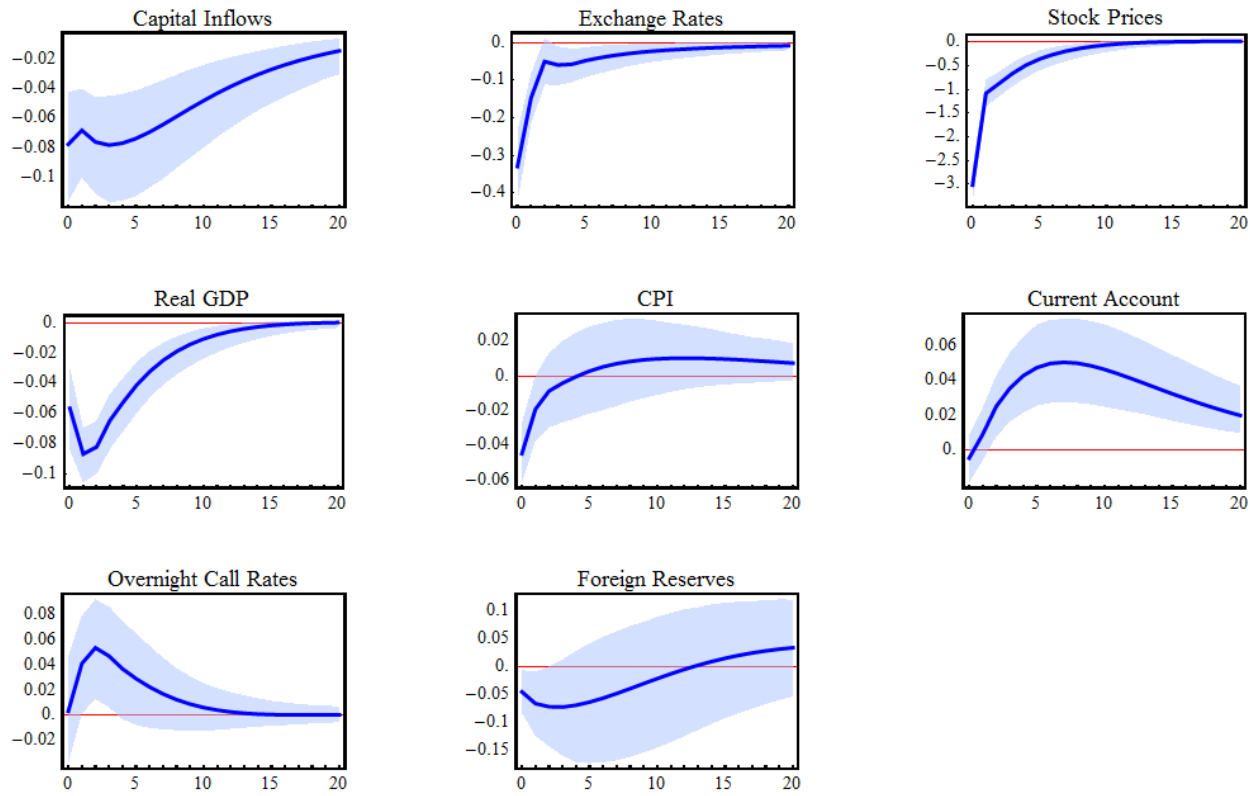

Notes: Above are shown EME responses in percentage points (up to 20 quarters) to a one-percent-point increase in the U.S. federal funds rate and concomitant changes in the U.S. real interest rate. The shaded areas mark the confidence bands between $16 \%$ and $84 \%$, constructed by the Bayesian Monte Carlo integration method.

directly decreases aggregate demand as evidenced by weak output and sluggish CPI inflation. The weak GDP growth and low inflation we find here are in contrast with earlier work by Canova (2005) in which Latin American countries are found to experience an increase in GDP within a year after the shock and immediate inflation. He extracts the U.S. macroeconomic and monetary shocks from a VAR model and feeds them into a VAR model of individual Latin American countries. He rationalizes this outcome by means of simultaneous increases of interest rates in Latin American countries, which boost capital inflows. IMF (2013) is a recent study that analyzes the impact of the U.S. monetary shock on other countries. Although its approach to measuring the U.S. policy shock on the output of other countries differs from ours in several aspects, such as the selection of shock-receiving countries (EME vs EME and AD 
countries), the measure of output (real GDP vs. industrial production), and data frequency (quarterly vs monthly), we find that its results are largely consistent with ours.

As shown in the third row of Figure 1, domestic authorities' responses with respect to their policy rates and foreign reserves are limited. The response of policy rates - about a 5 bps rise for a 1 percent hike in the U.S. policy rate - is lukewarm and weaker than what is seen in other studies, such as Frankel et al. (2004) and Edwards (2010, 2015). Frankel et al. suggests a full transmission of U.S. interest rates to the rest of world, especially to those countries under fixed exchange rate regimes in the 1990s. In a similar vein, the following studies seek to identify how much countries adjust interest rates in response to changes in the U.S. monetary policy stance. Valente (2009) finds that discretionary policy actions by the FOMC have smaller influences on interest rates in Hong Kong and Singapore than policy changes based upon macroeconomic fundamentals do. Edwards (2010) finds rapid adjustments in Latin American countries but slow adjustments in Asian countries to changes in the U.S. monetary stance, arguing that such differential adjustments are attributable to capital mobility. Kim and Yang (2009) find that Asian countries under flexible regimes significantly adjust their interest rates in response to U.S. monetary policy changes, but their exchange rate responses are muted. They attribute this finding to fear of floating. On the other hand, Lubik and Schorfheide (2006) based upon an estimated DSGE model report a limited transmission of U.S. monetary shocks to Europe. We will revisit this issue when discussing differentiation among EMEs.

We use data beyond the GFC, while most studies on monetary spillovers focus on periods prior to the GFC when the U.S. federal funds rate was not constrained by its zero lower bound. Two developments may have resulted in the low contagion of monetary policy from the U.S. to EMEs. The foremost cause is, of course, the federal funds rate at its zero lower bound. Although the U.S. policy rate stayed at this level for seven years, most EMEs reacted to the waves of global liquidity stemming from the vigorous unconventional monetary policy of the U.S. Federal Reserve. Second, most existing studies on monetary 
contagion take the U.S. as the epicenter and largely abstract out the contribution of other advanced countries, while other advanced countries also have contributed to the supply of GL. The synchronization in the supply of global liquidity among advanced countries that was witnessed prior to the GFC is at odd with recent divergences in monetary policy among advanced economies. Our work takes a conservative position in that only the contribution of the U.S. in the supply of global liquidity is put into the exercise while the secondary global liquidity generated from other advanced countries is turned off.

A recent study by Edwards (2015) finds relatively strong spillovers of U.S. monetary policy to emerging markets in Asia and Latin America-33 to 74 bps increases of policy rates in EMEs. He uses data from the 2000-2008 period, during which U.S. monetary tightening was more attributable to U.S. inflation rather than the global business cycle. U.S. policy after the GFC, however, seems to have been concerned about the slow recoveries in domestic output and jobs, and the relatively fast recoveries in EMEs after the crisis may have loosened the cross-border link of monetary stances between the U.S. and emerging markets. ${ }^{1)}$ Dées et al. (2010) find moderate policy spillovers from the U.S. to 33 sample countries; the median spillover is 2 bps against a U.S. policy rate hike of $22 \mathrm{bps}$.

The present empirical model also measures the effect of domestic policy rates in EMEs. The main difficulty in assessing the effect of domestic monetary policy in EMEs is controlling for monetary and financial shocks from advanced countries. The three global liquidity momenta play the role of control variables. However, we must accept that the empirical model lacks a link between EMEs and global business cycles. We employ recursive restrictions to identify the domestic monetary shock, placing variables in the following order: CPI inflation, real GDP, current account, capital inflows, foreign reserves, overnight call rates, stock prices, and nominal effective exchange rates. We place

1) While Edwards (2015) deals with a long-run policy contagion from the U.S. to some EMEs, our study focuses on the dynamic responses of EMEs to global liquidity shocks driven by G5 monetary policy. For this purpose, we draw changes in the U.S. policy rate, controlling for U.S. real GDP growth and inflation of producer prices. Edwards' estimation focuses on the long-run contagion, employing an error correction model, while we estimate short-term spillover based upon the VAR approach. 
Figure 2. EME Responses to a Domestic Policy Rate Hike
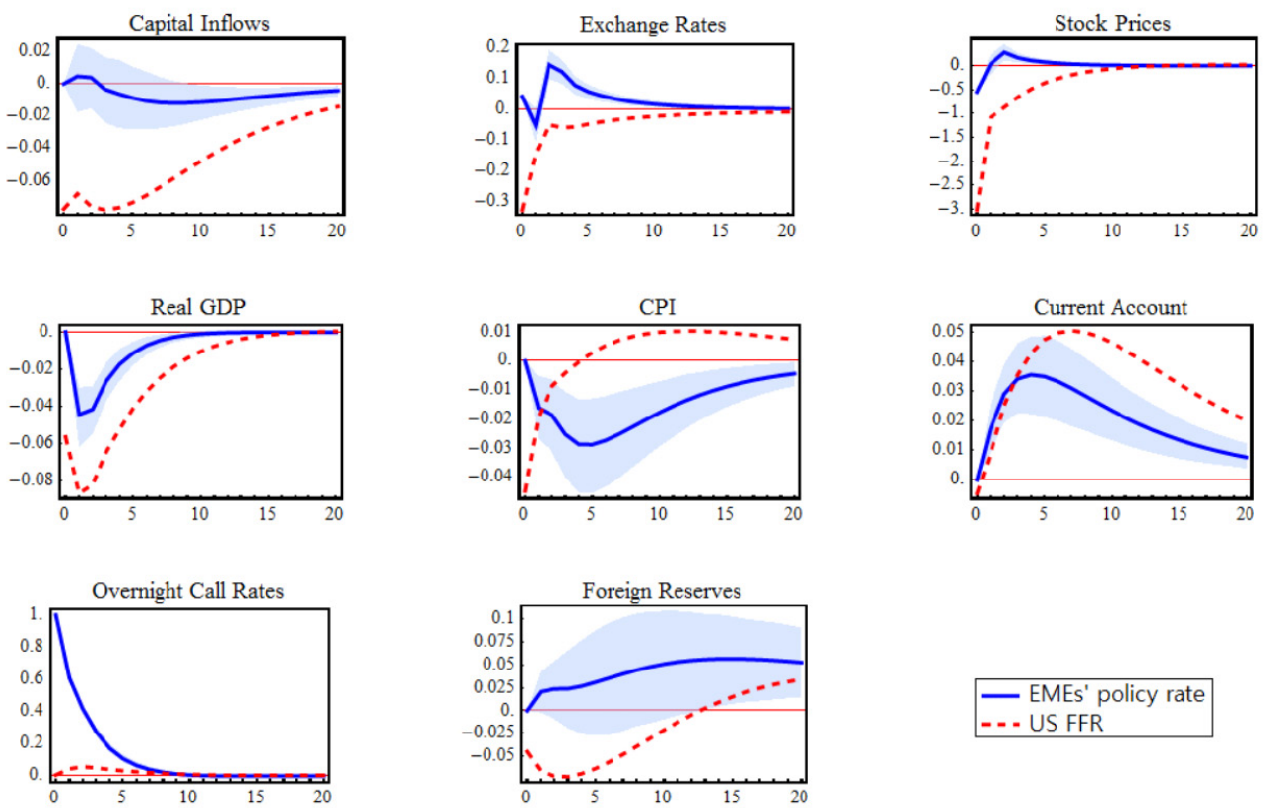
- - US EFR

Notes: The figure shows EME responses in percentage points to a one-percent-point increase in the domestic policy rate, along with those responses shown in Figure 1 for comparison. The shaded areas mark the bands between $16 \%$ and $84 \%$, constructed by the Bayesian Monte Carlo integration method.

slow-moving real-sector variables ahead of variables reflecting financial flows. We assume that monetary policymakers in EMEs set their policy rates responsively to innovations in real-sector and financial-flow data. Finally, we allow asset prices and nominal effective exchange rates to react to domestic monetary shocks. We find that it is essential to have the aforementioned sequence over the groups of variables - such as real sector, financial flows, policy measures, and asset prices - to obtain reasonable responses, but that any change in sequence within each group has little impact on the results.

Figure 2 depicts impulse responses to a one-percent-point increase in the domestic policy rate of EMEs, along with the responses to the U.S. policy rate hike for comparison. Domestic monetary tightening calls for initially moderate 
capital inflows, which are followed by a lagged reversal, and domestic currency appreciations in two quarters with lower inflation and current account surplus. Stock prices drop initially but quickly rebound. Output growth, inflation, and current account at their peaks have much smaller responses to the domestic policy rate hike than to the U.S. policy rate hike.

Although output growth and current account show similar response patterns across the two exercises, inflation exhibits different responses. Domestic policy tightening brings about a sluggish reaction in prices, consistent with earlier findings on the effect of U.S. monetary shocks on inflation, such as Romer and Romer (2004) and Christiano, Eichenbaum and Evans (1999), whereas U.S. policy tightening entails an immediate fall in inflation in EMEs. These contrasting reactions may be attributable to different patterns in pricing. In the face of global liquidity tightening, importers can more readily adjust their prices taking into account strategic responses of their domestic competitors and foreign suppliers owing to lower global demand. In contrast, domestic liquidity tightening leads to declines in domestic demand, exerting downward pressures on local prices. Another explanation is that global liquidity tightening may exert downward pressures on energy and commodity prices, which are heavily influenced by global demand and largely priced in U.S. dollars, whereas domestic liquidity tightening affects the domestic prices of items with local currency pricing.

The responses of EME output growth and inflation are largely consistent with findings from estimated New Keynesian open economy models, such as Adolfson et al. (2007 and 2008), except for the timing of responses in output growth and inflation. In our study, output immediately declines upon the domestic as well as U.S. monetary tightening, but inflation reacts slowly to the domestic monetary shock. Our finding that output growth responses precede inflation responses is similar to the major studies based on U.S. data (for example, Christiano et al., 1999, 2005).

EMEs are found to absorb a part of incoming investments in their foreign reserves after domestic monetary tightening. This policy move is likely to limit the effect of the policy rate lift to some degree by curbing domestic currency 
appreciation. Policymakers may choose this course of intervention to moderate the impacts of hot money flows on inflation in part through sterilized intervention, which results in foreign reserve accumulation and dampened responses in exchange rates. Alberola et al. (2014) in their panel analysis find foreign reserves in EMEs have stabilizing effects on capital inflows during global financial turmoil, reporting a significant cross term of the EMBI+ spread and international reserves that moderates the first-order effect of the spread in reducing capital inflows to EMEs.

\section{Effects on components of capital flows}

The previous section finds that global liquidity shrinkage causes overall outflows of foreign investments from EMEs. The IMF categorizes capital flows into portfolio investments, direct investments, and other investments. Portfolio investments are divided further into bond investments and equity investments. Using IMF data, we look into whether the withdrawal of global liquidity has diverse effects across different categories of capital inflows to EMEs.

In response to tighter U.S. monetary policy, all the categories of capital inflows show different degrees of substantively weakened inflows (see dotted lines in Figure 3.2) The most significant change in capital flows takes place in foreigners' investments in domestic bonds. Equity inflows are only marginally affected by the change in GL. Direct investments by foreigners increase initially but soon reverse to significantly negative figures.

The solid lines of Figure 3 depict how a domestic policy rate hike affects foreigners' investments in EMEs. Tighter domestic policy on average has smaller impacts on capital flows than U.S. tighter policy does, and its impacts are significant only for bond inflows. This finding suggests that adjusting policy rates in EMEs to handle capital flows could largely be ineffective.

2) Broner et al. (2013) examine the impacts of banking, currency, and debt crises on capital flow components. They find declines in capital inflows during crises across all the components for upper-middle-income and lower-middle-income countries. 
Figure 3: EME Responses of Capital Inflows to Global and Domestic Monetary Policy Shocks
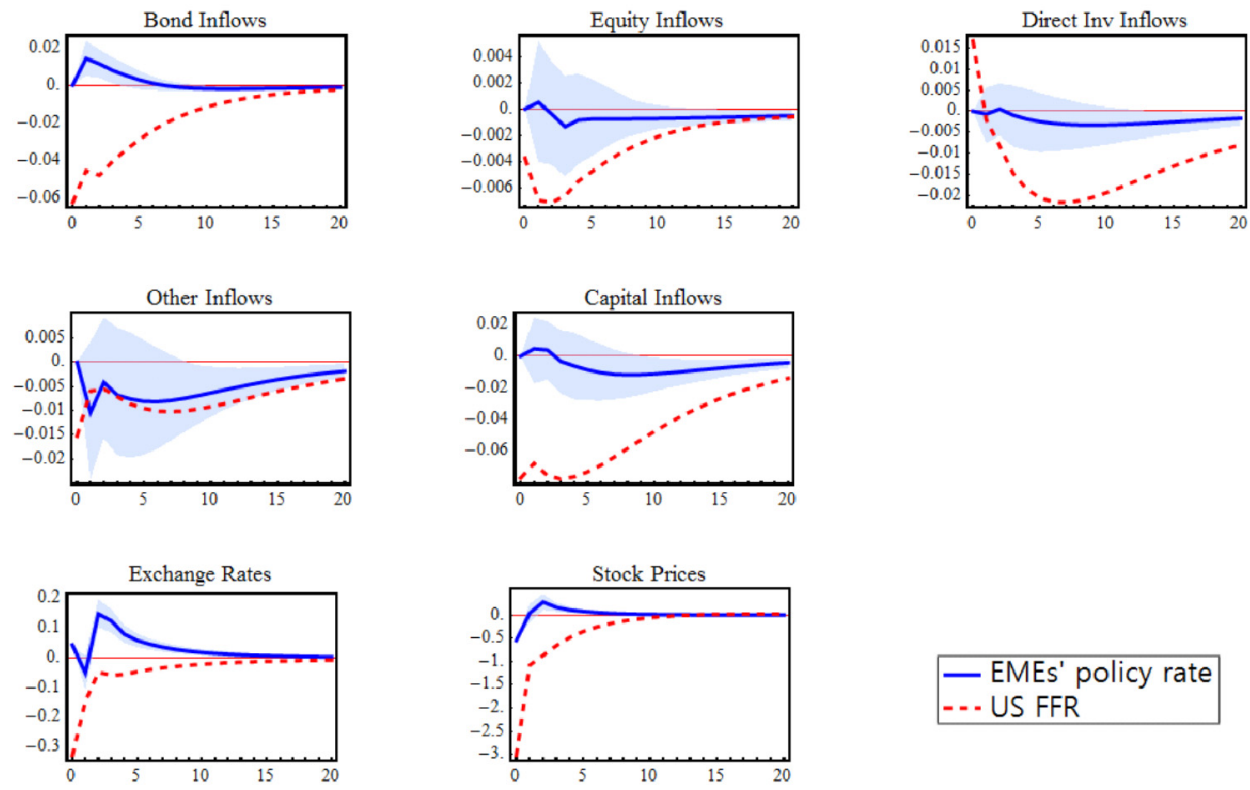

Notes: Above are shown capital inflows as a percent of GDP to EMEs (up to 20 quarters) after a one-percent-point increase in the U.S. federal funds rate (dotted line) and an increase in the domestic policy rate of the same magnitude (solid line). The shaded areas mark the bands between $16 \%$ and $84 \%$ for the domestic policy rate increase, constructed by the Bayesian Monte Carlo integration method.

\section{Divergent EME Responses to U.S. Monetary Policy Shocks}

\section{Do EME responses depend on economic fundamentals?}

In the previous section, we have found that the withdrawal of global liquidity causes changes in output growth and inflation in EMEs. The welfare consequences of this development may be different across countries, and we now look into what factors are behind this divergence. There are a number of welfare approximations in terms of key macroeconomic variables, basically extending the approximation for a closed economy proposed by Woodford (2003). These approximations are usually called loss functions, which are 
deemed as objective functions of policy authorities. For an open economy, Corsetti et al. (2010) derive approximations that apply to two-country models with various sets of economic structure. A standard approximation for a closed economy comprises the output gap and inflation. The approximations for an open economy could be augmented with additional terms such as inflation of imports, terms of trade, deviations from the law of one price or deviations from exchange rates under perfect risk sharing, depending on assumptions about economic structure regarding financial market completeness and import price setting. We consider four variables to measure the welfare consequences of global liquidity withdrawal: real GDP growth, CPI inflation, exchange rate changes, and capital inflows. We include capital inflows in light of escalating concerns about capital flows in open economies and the necessity for capital flow management to gain monetary independence, notably as in Farhi and Werning (2014). We measure the deviation of each variable from the steady state for a three-year period. ${ }^{3)}$

We employ a grouping approach similar to Lustig and Verdelhan (2007).4) An alternative method to investigate the link between country characteristics and certain statistical outcomes is regressing the outcomes on country characteristics as in Miniane et al. (2007). A typical approach is running country-level VARs with limited lags and variables, obtaining statistical outcomes, such as impulse responses, and finally regressing the outcomes on the variables of country characteristics. This approach, however, has three drawbacks: ( i ) observation inaccuracy owing to limited degrees of freedom; (ii) sample uncertainty in the second-stage regression owing to treating the outcome from the first-stage analysis as a direct observation;5) and (iii) evolving

3) This method of measuring deviation for a single variable differs somewhat from the typical measurement of the loss function but retains information on the direction of responses and facilitates comparison with other studies.

4) Lustig and Verdelhan (2007) form portfolios from government bonds of sample countries such that each portfolio includes a group of government bonds with similar levels of interest rate, and bonds are dynamically assigned to each portfolio. Thus, the government bonds of a single country may belong to different portfolios over time. The behavior of low- or high-yield currencies can be directly analyzed through portfolios.

5) Miniane et al. (2007) mitigates the second issue by re-sampling the outcome from the distribution derived from the first-stage VAR. 
Figure 4: EME Fundamentals and Welfare-relevant Measures after U.S. Monetary Tightening

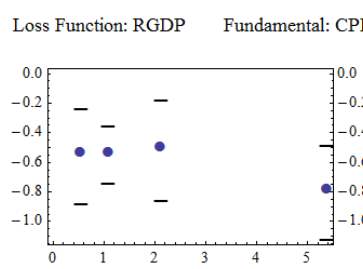

Loss Function: CPI Fundamental: CPI

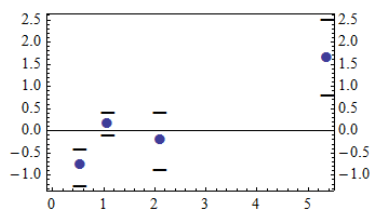

Loss Function: NEER Fundamental: CPI

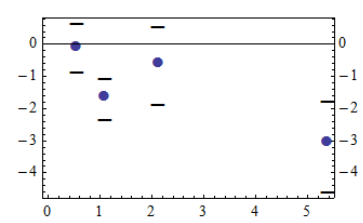

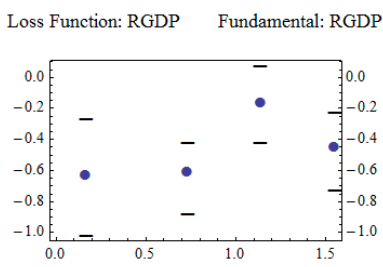

Loss Function: CPI Fundamental: RGDP

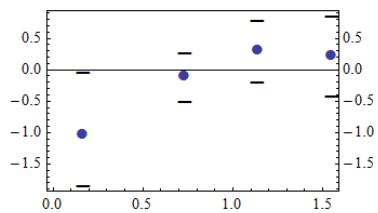

Loss Function: NEER Fundamental: RGDP

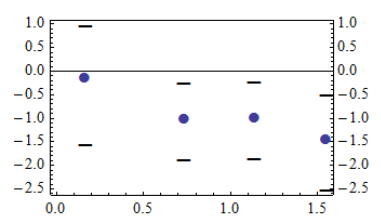

Loss Function: $\mathrm{CF} \quad$ Fundamental: $\mathrm{CF}$

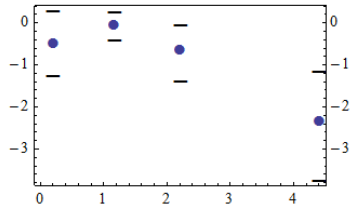

Loss Function: $\mathrm{CF} \quad$ Fundamental: SP

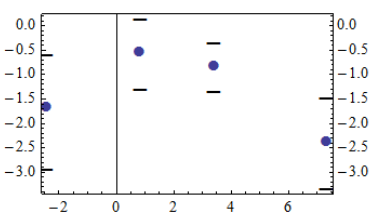

Loss Function: $\mathrm{CF} \quad$ Fundamental: NEER

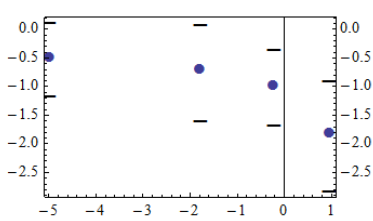

Notes: Points in each panel depict the relationship between a measure of fundamentals and a measure of the loss function. In each panel, the x-axis stands for the 3-year average of a fundamental variable and the $y$-axis for the 3-year accumulation of the impulse response after U.S. monetary tightening. All figures are in percentage points, and real GDP growth (RGDP), CPI inflation (CPI), stock price increase (SP) and nominal exchange rate change (NEER) are presented on a quarter-over-quarter basis and not at an annualized rate. Bars above and below dots mark the bands between $16 \%$ and $84 \%$.

country characteristics over time. The grouping method we use is free of all of the above issues.

We divide 19 EMEs per period into four groups according to their characteristics prior to the period. For example, we split 19 EMEs into four groups for the first quarter of 2001 according to their average CPI inflation during the period from 1998 to 2000 . We do the same partitioning exercise with respect to other fundamentals such as output growth, exchange rate growth, current account balance, foreign reserve ratio, stock price growth, and capital flow ratio. Among the four groups for each indicator, the first group has 
the countries with the lowest values in the indicator. We form a panel from each group and apply the panel FAVAR model, finally measuring a loss function value for each group against the global liquidity shock. Figure 4 reports the most informative combinations among the exercises, and Figures A1 and A2 have the exhaustive sets from the exercise.

We find that CPI inflation has discernable welfare consequences with respect to real growth, CPI inflation and exchange rates from the first column of Figure 4. Countries that experienced high inflation for the previous three years are likely to experience more drastic output loss, higher inflation and larger depreciation than their moderately inflationary counterparts. The most inflationary group will experience a severe real depreciation in the event of global liquidity withdrawal while the least inflationary group will experience moderate real appreciation due to the deflationary effect of liquidity loss and stable exchange rates against the shock.

The real GDP growth rates of EMEs in our samples are more evenly distributed than CPI inflation, as observed by the horizontal distance of points in the first and second column of the figure. A similar pattern of effects on real exchange rates is observed in groups partitioned by real growth rates. Countries that have grown faster than other EMEs experience a larger degree of real depreciation, as shown in the second column of the figure. The loss of growth due to U.S. monetary tightening is least severe for the group with the second highest growth performance prior to the arrival of the shock. The nonlinear pattern shown here may suggest that extremely high growth in an emerging market country may build up vulnerability to external risk.

The third column of the figure pertains to capital inflow responses to tighter U.S. monetary policy. Countries that experienced larger capital inflows, significant gains in stock values, and relative strengthening of their currencies prior to the shock are prone to see capital inflow reductions after the shock. Using country-panel regressions, Broner et al. (2013) find evidence of retrenchment in capital inflows during a three-year period following a country-specific shock in lower- and upper-middle-income countries. Our finding here suggests that retrenchment in capital inflows after a U.S. interest 
rate hike depends on the magnitude of inflows prior to the shock. ${ }^{6}$ )

We do not find a clear dependence of capital flow responses to tighter U.S. monetary policy on the level of foreign reserves (see Figure A2 in Appendix). Alberola et al. (2014) find that the magnitude of decrease in capital inflows into EMEs due to global financial stress (measured by the EMBI+ spread) is low for countries with moderate foreign reserves (as fractions of international liabilities) and high for countries with low or high foreign reserves. Policy authorities can build up foreign reserves to temper the country's vulnerability to sudden stops in capital flows. Provided that the level of foreign reserves is partially effective in curbing sudden stops in capital flows, the non-linear pattern as in the aforementioned study is not necessarily inconsistent with the lack of a clear link between foreign reserves and reduced capital inflows due to U.S. policy tightening.

\section{Does the level of inflation matter in transmitting policy shocks?}

This subsection explores divergent EME responses stemming from cross-border diversity in inflation and their welfare implications. Since the level of CPI inflation offers a clear demarcation of macroeconomic management among EME countries, we divide 19 EMEs into two groups: high-inflation and low-inflation groups. ${ }^{7)}$ The high-inflation group has seen a 14 percentage point increase per annum in their price levels during the sample period, while low-inflation group has experienced only 4 percent inflation on average.

Figure 5 shows that high-inflation countries are more susceptible to a

6) The previous inflows of foreign capital are found to affect the magnitude of foreign investment reversal in response to a U.S. interest rate hike but to have little impacts on growth and inflation. This finding is odd with the concern that financial openness may be related to external vulnerability. There are two possible explanations on the matter. First, financial openness is an endogenous outcome of an economy rather than exogenously determined institutions. In an economy that is capable of manage capital inflows while gaining the benefit of them, policymakers are more likely to initiate or accelerate the process of financial liberation. Second, our measure is about the flows of capital rather than stock and the financial openness of a certain country is better proxied by stock of inbound investments.

7) The high-inflation group comprises Argentina, India, Hungary, Mexico, Indonesia, Russia, Romania, Bulgaria, and Turkey. The low-inflation group includes the rest of the sample countries except for Brazil, which is at the mid-point among EMEs in terms of CPI inflation. 
Figure 5: Responses of High-inflation and Low-inflation EME Groups to the U.S. Federal Funds Rate Hike
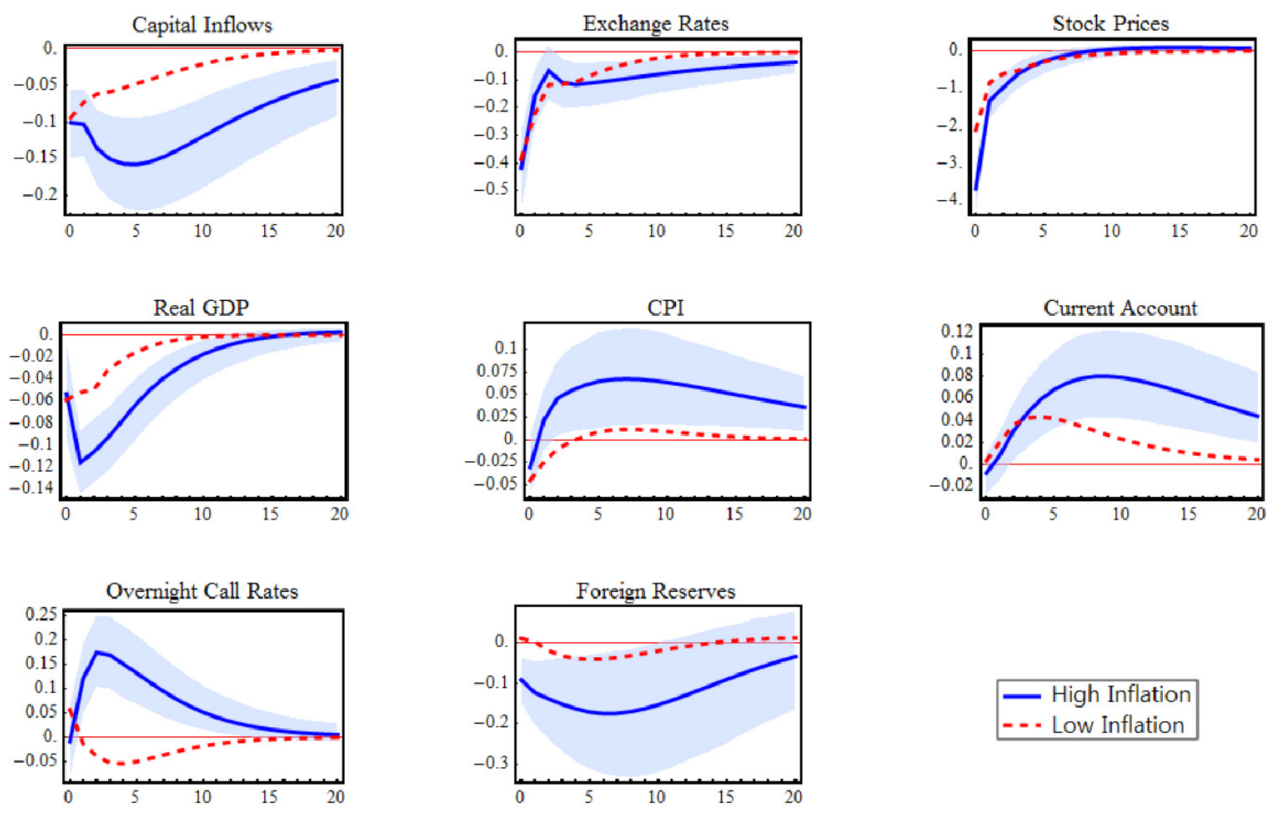

Notes: The figure summarizes the responses of two EME groups after a one-percent-point increase of the U.S. federal funds rate using a panel FAVAR model for each group. The unit of the $y$-axis is percentage points. The shaded areas mark the confidence bands between $16 \%$ and $84 \%$ for the low-inflation group, constructed by the Bayesian Monte Carlo integration method.

one-percentage-point hike in the U.S. federal funds rate in terms of capital flows and policy rates, and consequently foreign reserves, output growth, and inflation. The welfare consequences are in part affected by domestic policy responses, especially changes in policy rates. High-inflation EMEs raise their policy rates in response to tighter U.S. monetary policy in an effort to retain capital inflows or prevent capital outflows, consistent with the argument for policy spillovers. Interestingly, the low-inflation EMEs lower their policy rates after an initial rise, which is possibly conducive to shoring up stock prices and boosting aggregate demand. Despite positive responses in domestic policy rates, capital inflows are unfavorable for the high-inflation group. 


\section{Table 1: Divergent Impacts of Global and Domestic Monetary Policy Shocks on EME Groups}

\begin{tabular}{lllrrr} 
& & All & High Inflation(H) & Low Inflation( $(\mathrm{L})$ & Difference $(\mathrm{H}-\mathrm{L})$ \\
Global Liquidity & Real GDP & -0.49 & -0.69 & -0.26 & -0.43 \\
& CPI & -0.02 & 0.61 & -0.01 & 0.62 \\
& Current Account & 0.44 & 0.67 & 0.36 & 0.31 \\
& Exchange Rates & -0.33 & -0.42 & -0.39 & -0.03 \\
& Overnight Call Rates & 0.05 & 0.17 & 0.06 & 0.12 \\
& Foreign Reserves & -0.60 & -1.82 & -0.29 & -1.54 \\
& & & & 0.04 \\
Domestic Liquidity & Real GDP & -0.16 & -0.17 & -0.21 & 0.49 \\
& CPI & -0.26 & -0.13 & -0.62 & -0.50 \\
& Current Account & 0.33 & 0.24 & 0.74 & -0.23 \\
& Exchange Rates & 0.15 & 0.10 & 0.33 & -2.00 \\
\hline & Foreign Reserves & 0.46 & -0.12 & 1.88 & 0.5 \\
\hline
\end{tabular}

Notes: The table summarizes impulse responses of EMEs to a one-percent-point increase in the U.S. (global) policy rate and in (domestic) policy rates of EMEs. Real GDP and CPI represent cumulative responses of output growth and CPI inflation in percentage points, respectively, to the corresponding shock. Current Account and Foreign Reserves represent cummulative responses of account balance and foreign reserves, respectively, (both as percentages of nominal GDP) for three years to the corresponding shock. Exchange Rate and Overnight Call Rate are measured by the largest response to the corresponding shock during the first 3 years, both being in percentage points.

In terms of output growth and inflation, low-inflation EMEs absorb the shock with a lesser swing than high-inflation EMEs, as summarized in Table 1. Exchange rates and stock prices exhibit little quantitative differences. The real depreciation of the high-inflation group exceeds that of low-inflation group because the former experiences much higher inflation after the first period than the latter does, while they see similar magnitudes of currency depreciation. As a result, the high-inflation group has more room for mercantile advantage over the low-inflation group, thereby reaping higher rises in the current account.

On the basis of the welfare measures we used in the previous exercise, the output loss of the high-inflation group is larger than that of low-inflation group. Upon tighter U.S. monetary policy, the high-inflation group would have more 
Figure 6. Counterfactual Exercise of High-inflation EMEs Taking the Shock-absorbing Process of Low-inflation EMEs
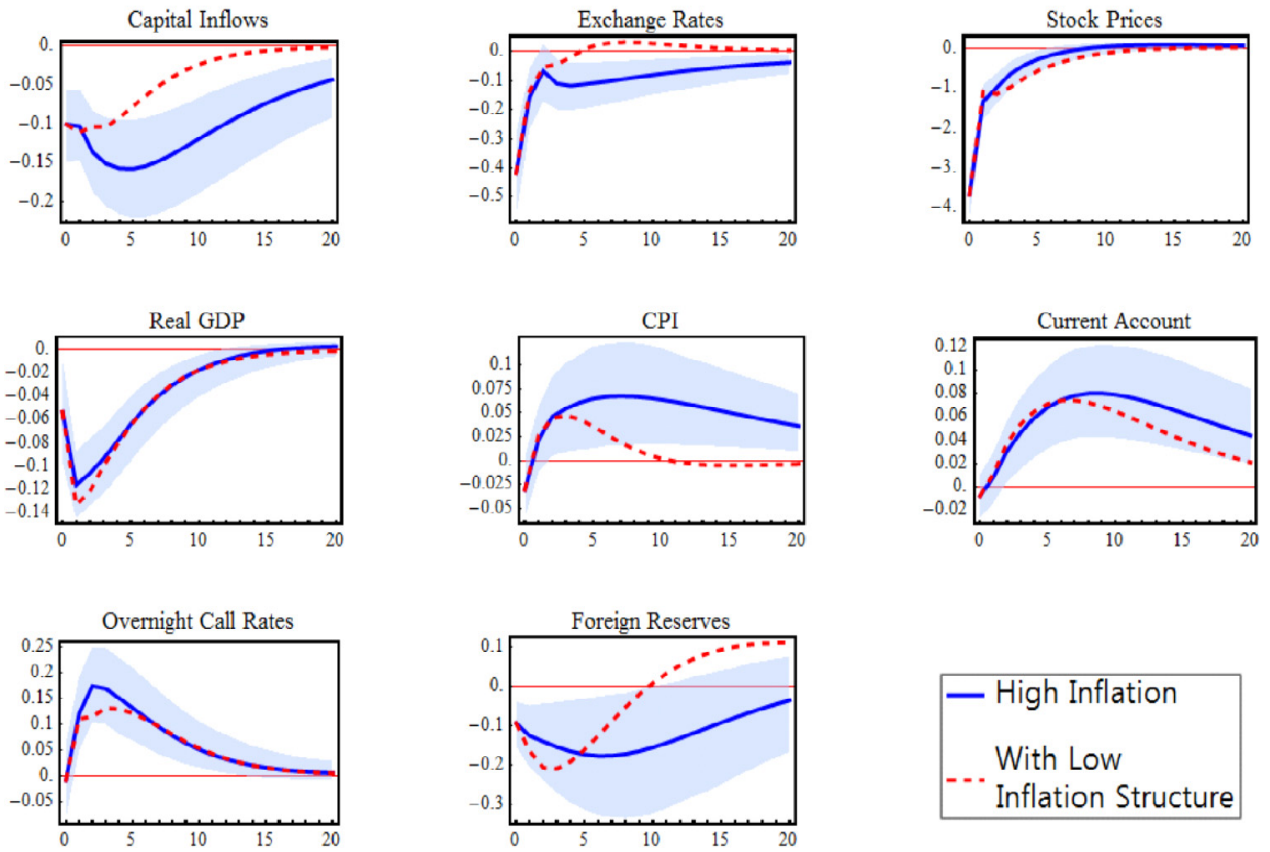

Notes: The figure summarizes a counterfactual exercise by which the high-inflation group takes the shock-absorbing process of the low-inflation group in terms of the dynamic structure of lagged endogenous variables. Shaded areas around the solid lines mark the confidence bands between $16 \%$ and $84 \%$ of the high-inflation group. The unit of the $y$-axis is percentage points.

diverse price responses with higher inflation than the low-inflation one would, as implied by the perspective of New Keynesian sticky price models. All of the welfare-relevant measures indicate that the high-inflation group fares much worse than the low-inflation group.

\section{Counterfactual exercise: mimicking low-inflation economies?}

Broadly speaking, the divergent responses of the two EME groups are attributable to EMEs' differential reactions upon the arrival of the shock and their absorbing processes afterwards. What could be the possible causes of such 
divergent responses? We attempt to determine whether the distinction comes from the reaction on the immediate responses of EMEs as expressed in the matrix B's in equation (2), or the shock-absorbing domestic structure as expressed in the matrix A's.

We employ a method used by Stock and Watson (2003), specifically, replacing the estimate of $\mathrm{A}$ in equation (2) of the high-inflation group with the corresponding estimate of the low-inflation group. The counterfactual and original responses of the high-inflation group are collated in Figure 6. The dashed line of each panel shows how the high-inflation group would absorb the shock if they had domestic economic structures resembling those of the low-inflation group. Note that a global liquidity shock may have diverse initial impacts on the two groups, which are implied by the estimate of B in equation (2). Choi et al. (2014) offer a counterfactual exercise to analyze how alternative policy responses to the arrival of the global liquidity shock affect economic outcomes.

As shown in Figure 6, gains to the high-inflation group from mimicking the low-inflation group dynamics are limited to lower capital outflows, foreign reserve drains, and inflation, along with reduced currency depreciation. The absence of gains in buffering output loss against the shock implies that improving immediate policy responses and other forefront responses, for example through beefing up resilience of the financial sector, would be of the first order importance in curbing the loss from the shock.

It is noteworthy that policymakers in high-inflation groups would not change their policy rate reactions much over time even if they were to have the same economic structure as the low-inflation group, as implied by the comparison between Figures 5 and 6 . Improvement in inflation responses despite a marginal deterioration in output growth may nonetheless somewhat warrant arguing that the adoption of the domestic economic structure of the low-inflation group would improve the welfare of the high-inflation group if the weight on inflation is high enough in their welfare metrics. ${ }^{8)}$ 


\section{Conclusions}

This paper investigates the impacts of U.S. and domestic monetary policy on EMEs and attempts to link the driver of divergent responses to fundamentals. U.S. monetary tightening by a one-percentage-point increase in the federal funds rate reduces the output growth of EMEs on average by a half percentage point. Among EME capital markets, bond markets are expected to be most significantly affected by U.S. monetary policy. In addition, EMEs show divergent policy responses and their macro-financial responses differ depending upon their economic fundamentals in the face of tighter U.S. policy. In particular, we find that high-inflation than low-inflation EMEs are more susceptible to the shock stemming from a U.S. federal funds rate hike.

8) Apart from welfare gains from the improved responses of capital inflows and exchange rates, the gain from moderate inflation may outweigh the loss from output growth. Of course, this argument depends on the weights placed on inflation and output gap in the loss function. For an open economy, the relative weights between output gap and inflation are same as those of a closed economy as in Woodford (2003), although inflation in the loss function usually stands for inflation of domestic goods (see Corsetti, 2010). A typical calibration of parameters results in a low weight placed on the output gap. Even if we use a higher weight on the output gap as argued by Debortoli et al. (2015), the counterfactual outcome is still preferable to the original outcome. 


\section{References}

Adolfson, M., S. Laséen, J. Lindé, and M. Villani (2007), "Bayesian Estimation of an Open Economy DSGE Model with Incomplete Pass-through," Journal of International Economics, Vol. 72(2), pp. 481-511.

Adolfson, M., S. Laséen, J. Lindé, and M. Villani (2008), "Evaluating an Estimated New Keynesian Small Open Economy Model," Journal of Economic Dynamics and Control, Vol. 32(8), pp. 2690-2721.

Alberola, E., A. Erce, and J. M. Serena (2014), "International Reserves and Gross Capital Flows Dynamics," Fondo Latinoamericano de Reservas Discussion Paper, No. 3.

Broner, F., T. Didier, A. Erce, and S. L. Schmukler (2013), "Gross Capital Flows: Dynamics and Crises," Journal of Monetary Economics, Vol. 60(1), pp. 113-133.

Canova, F. (2005), "The Transmission of U.S. Shocks to Latin America," Journal of Applied Econometrics, Vol. 20(2), pp. 229-251.

Choi, W. G., T. Kang, G.-Y. Kim, and B. Lee (2014), "Global Liquidity Momenta and EMEs' Policy Responses,” BOK Working Paper, No. 2014-38.

Christiano, L. J., M. Eichenbaum, and C. L. Evans (1999), "Chapter 2 Monetary Policy Shocks: What Have We Learned and to What End?" Handbook of Macroeconomics, Elsevier, Vol. 1, Part A, pp. 65-148.

Christiano, L. J., M. Eichenbaum, and C. L. Evans (2005), "Nominal Rigidities and the Dynamic Effects of a Shock to Monetary Policy," Journal of Political Economy, Vol. 113(1), pp. 1-45.

Coibion, O. (2011), "Are the Effects of Monetary Policy Shocks Big or Small?" Discussion Paper, National Bureau of Economic Research.

Corsetti, G., L. Dedola, and S. Leduc (2010), "Optimal Monetary Policy in Open Economies," Handbook of Monetary Economics, B. M. Friedman and M. Woodford (eds.), Elsevier, Vol. 3, Chap. 16, pp. 861-933. 
Debortoli, D., J. Kim, J. Lindé, and R. Nunes (2015), "Designing a Simple Loss Function for the Fed: Does the Dual Mandate Make Sense?" CEPR Discussion Paper, No. DP10409.

Dees, S., M. Pesaran, L. V. Smith, and R. Smith (2010), "Supply, Demand and Monetary Policy Shocks in a Multi-country New Keynesian Model," European Central Bank Working Papers, No. 1239.

Farhi, E., and I. Werning (2014), "Dilemma Not Trilemma \& Quest; Capital Controls and Exchange Rates with Volatile Capital Flows," IMF Economic Review, Vol. 62(4), pp. 569-605.

Edwards, S. (2010), "The International Transmission of Interest Rate Shocks: The Federal Reserve and Emerging Markets in Latin America and Asia," Journal of International Money and Finance, Vol. 29(4), pp. 685-703.

Edwards, S. (2015), “Monetary Policy 'Contagion' in the Pacific: A Historical Inquiry," Presented at the Federal Reserve Bank of San Francisco Asia Economic Policy Conference.

Eichengreen, B. (2002), "Can Emerging Markets Float? Should They Target Inflation?" Banco Central Do Brasil Working Paper Series, No. 36.

Fraga, A., I. Goldfajn, and A. Minella (2004), "Inflation Targeting in Emerging Market Economies," NBER Macroeconomics Annual 2003, The MIT Press, Vol. 18, pp. 365-416.

Frankel, J., S. L. Schmuklier, and L. Serven (2004), "Global Transmission of Interest Rates: Monetary Independence and Currency Regime," Journal of International Money and Finance, Vol. 23(5), pp. 701-733.

Hannan, E. J., and B. G. Quinn (1979), "The Determination of the Order of an Autoregression," Journal of the Royal Statistical Society. Series B (Methodological), Vol. 41(2), pp. 190-195.

IMF, (2013), "World Economic Outlook," Washington: International Monetary Fund, Chap 3. 
Kahn, B. (2009), "Challenges of Inflation Targeting for Emerging-market Economies: The South African Case," Challenges for Monetary Policy-makers in Emerging Markets, No. 123.

Kim, S., and D. Y. Yang (2009), "International Monetary Transmission and Exchange Rate Regimes: Floaters vs. Non-floaters," Discussion Paper, ADBI Working Paper Series, No. 181.

Kim, S., and H. S. Shin (2015), "Offshore EME Bond Issuance and the Transmission Channels of Global Liquidity," mimeo.

Lubik, T., and F. Schorfheide (2006), "A Bayesian Look at the New Open Economy Macroeconomics," NBER Macroeconomics Annual 2005, The MIT Press, Vol. 20, pp. 313-382.

Lustig, H., and A. Verdelhan (2007), "The Cross Section of Foreign Currency Risk Premia and Consumption Growth Risk," The American Economic Review, Vol. 97(1), pp. 89-117.

Miniane J. and J. H. Rogers (2007), "Capital Controls and the International Transmission of U.S. Money Shocks," Journal of Money, Credit and Banking, Vol. 39(5), pp. 1003-1035.

Morgan, P. (2011), "Impact of U.S. Quantitative Easing Policy on Emerging Asia," ADBI Working Paper Series, No. 321.

Rey, H. (2015), "Dilemma Not Trilemma: the Global Financial Cycle and Monetary Policy independence," National Bureau of Economic Research, No. w21162.

Romer, C. D. and D. H. Romer, (2004), “A New Measure of Monetary Shocks: Derivation and Implications," The American Economic Review, Vol. 94(4), pp. 1055-1084.

Stock, J. H. and M. W. Watson (2003), "Has the Business Cycle Changed and Why?" NBER Macroeconomics Annual 2002, The MIT press, Vol. 17, pp. 159-230. 
Stock, J. H. and M. W. Watson (2005), "Implications of Dynamic Factor Models for VAR Analysis," National Bureau of Economic Research, No. w11467.

Valente, G. (2009), "International Interest Rates and U.S. Monetary Policy Announcements: Evidence from Hong Kong and Singapore," Journal of International Money and Finance, Vol. 28(6), pp. 920-940.

Woodford, M. (2003), Interest and Prices, Princeton University Press. 


\section{Appendix}

Figure A1: Fundamentals of Emerging Markets and Real GDP Growth and CPI inflation after U.S. Monetary Tightening

Loss Function: RGDP Fundamental: CPI

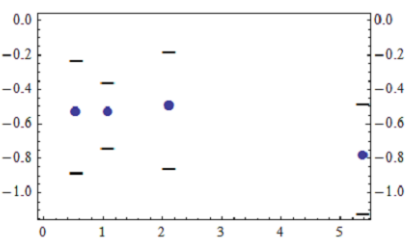

Loss Funetion: CPI Fundamental: RGDP

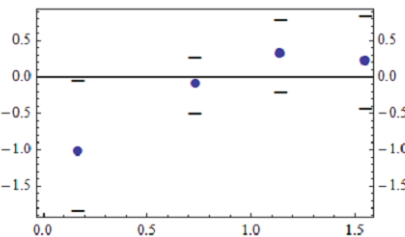

Loss Function: RGDP

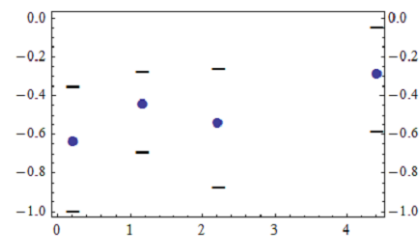

Loss Function: CPI Fundamental: FR

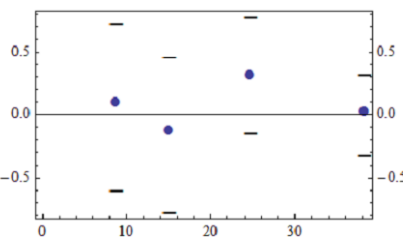

Loss Function: RGDP Fundamental: NEER

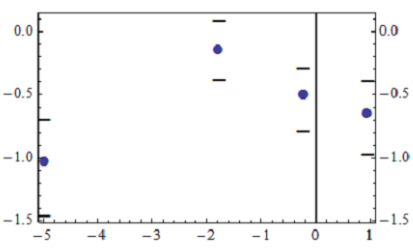

Loss Function: CPI Fundamental: CPI

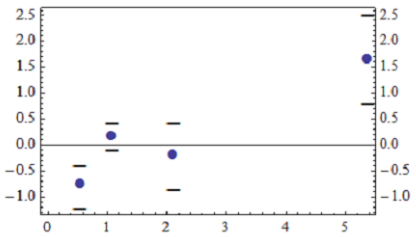

Loss Function: RGDP Fundamental: CA

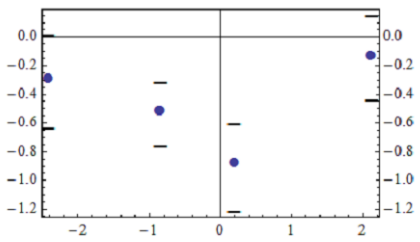

Loss Function: $\mathrm{CPI} \quad$ Fundamental: $\mathrm{CP}$

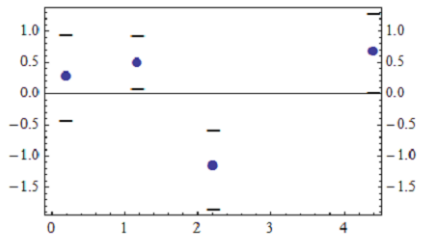

Loss Function: RGDP Fundamental: SP

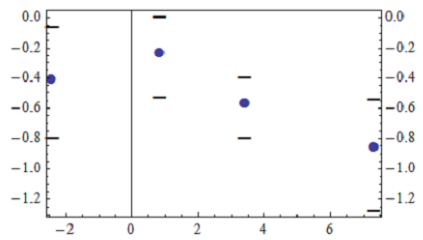

Loss Function: CPI Fundamental: NEER

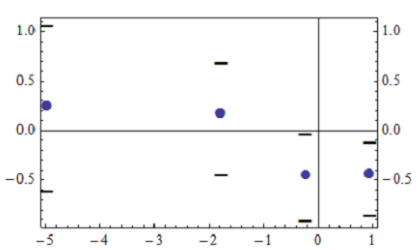

Loss Function: RGDP Fundamental: RGDP

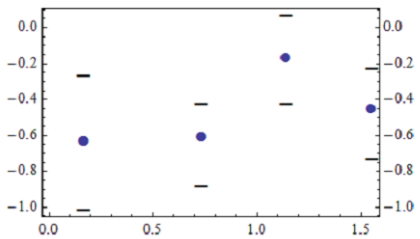

Loss Function: $\mathrm{CPI} \quad$ Fundamental: $\mathrm{CA}$

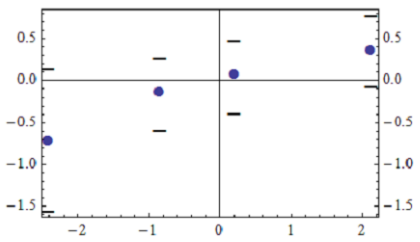

Loss Function: RGDP Fundamental: FR

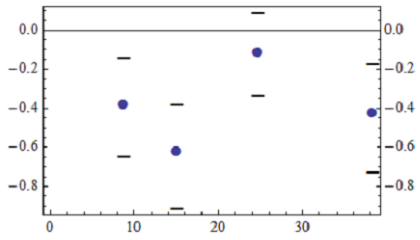

Loss Function: CPI Fundamental: SP

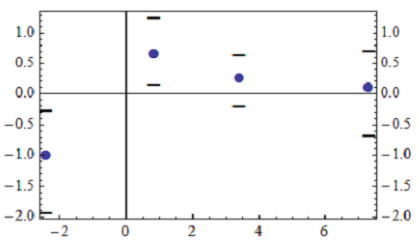

Notes: The figure depicts the comprehensive set for Figure 4 with respect to real GDP growth and CPI inflation. 
Figure A2: Fundamentals of Emerging Markets and Nominal Appreciation and Capital Inflows after U.S. Monetary Tightening

Loss Function: NEER Fundamental: CPI

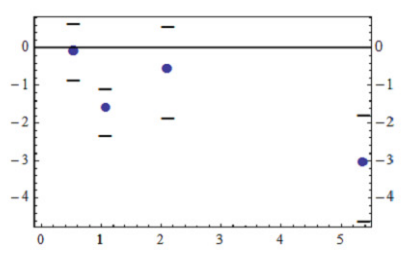

Loss Function: CF Fundamental: RGDP

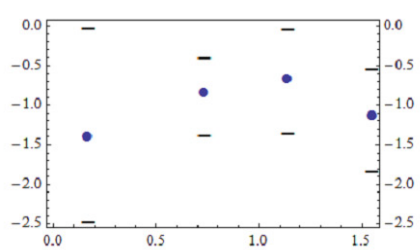

Loss Function: NEER Fundamental: CF

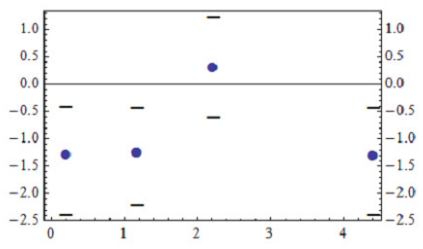

Loss Function: CF Fundamental: FR

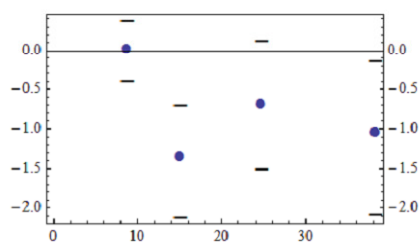

Loss Function: NEER Fundamental: NEER

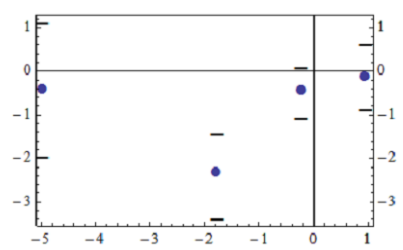

Loss Function: $\mathrm{CF} \quad$ Fundamental: $\mathrm{CPI}$

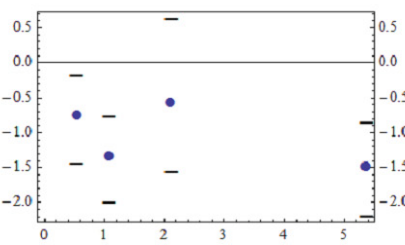

Loss Function: NEER Fundamental: CA

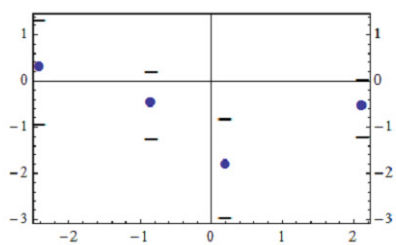

Loss Function: $\mathrm{CF} \quad$ Fundamental: $\mathrm{CF}$

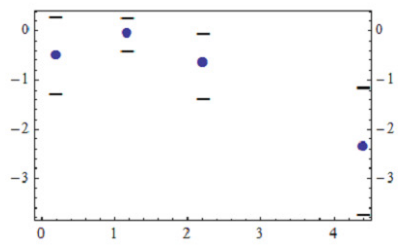

Loss Function: NEER Fundamental: SP

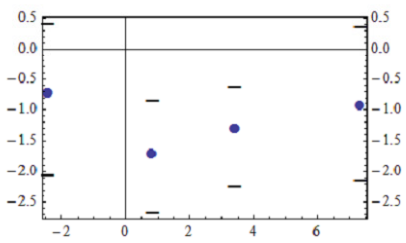

Loss Function: CF Fundamental: NEER

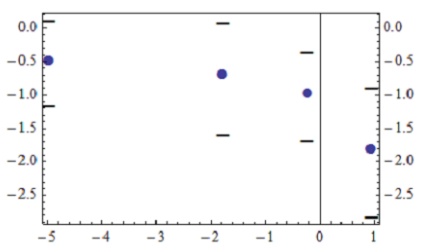

Loss Function: NEER Fundamental: RGDP

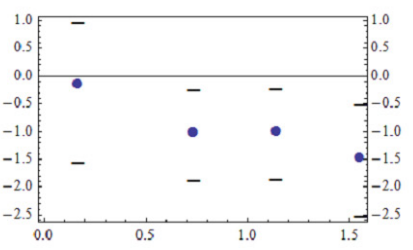

Loss Function: $\mathrm{CF} \quad$ Fundamental: $\mathrm{CA}$

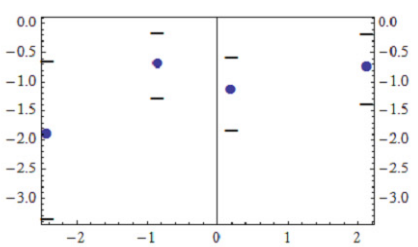

Loss Function: NEER Fundamental: FR

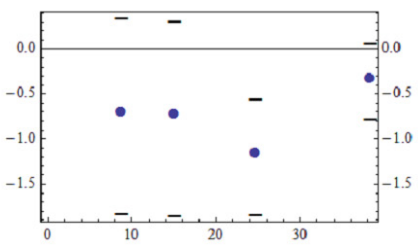

Loss Function: $\mathrm{CF} \quad$ Fundamental: SP

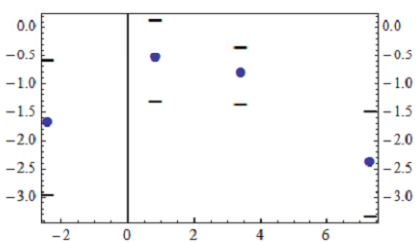

Notes: The figure depicts the comprehensive set for Figure 4 with respect to nominal exchange rate appreciation (NEER) and capital inflows (CF). 


\section{$<$ Abstract in Korean>}

\section{해외 및 국내 통화정책 충격이 신흥시장국에 미치는 영향}

최운규 *, 이병주**, 강태수***, 김근영***

본 연구는 미국 및 신흥 시장국의 긴축적 통화정책이 신흥국 경제에 미 치는 영향을 실증모형을 이용하여 분석하였다. 주요 추정결과는 다음과 같 다. 먼저, 미국의 정책금리 인상 충격이 신흥시장국의 금리 인상에 비해 신 흥국 경제성장에 더 큰 영향을 주는 것으로 나타났다. 또한, 미국의 금리인 상 충격은 신흥국의 경제성장률 및 물가상승률에 유의한 영향을 미치는 가 운데, 신흥국의 정책반응과 거시변수에 미치는 영향은 신흥국의 거시여건 에 따라 다르게 나타났다. 특히 물가상승률이 높은 신흥국일수록 미국의 긴 축정책에 따른 성장률 위축의 여파가 큰 것으로 나타났다.

핵심 주제어: 글로벌 유동성, 금융 전이, 통화정책 충격, 신흥시장국

JEL Classification: F32, F42

* 국제통화기금 Senior Economist (E-mail: wchoi@imf.org)

** 한국은행 경제연구원 국제경제연구실 부연구위원 (전화: 02-759-5435, E-mail: brian.lee@bok.or.kr)

*** 한국은행 조사국 산업고용팀 차장 (전화: 02-759-4208, E-mail: tskang@bok.or.kr)

**** 한국은행 조사국 국제종합팀 팀장 (전화: 02-759-5280, E-mail: kgy3104@bok.or.kr)

이 연구내용은 집필자 개인의견이며 한국은행의 공식견해와는 무관합니다. 따라서 본 논문의 내용을 보 도하거나 인용할 경우에는 집필자명을 반드시 명시하여 주시기 바랍니다. 


\section{$\mathrm{BOK}$ 경제연구 발간목록}

한국은행 경제연구원에서는 Working Paper인 ${ }^{\mathrm{B} B O K}$ 경제연구』를 수시로 발간하고 있습니다. 『BOK 경제연구』는 주요 경제 현상 및 정책 효과에 대한 직관적 설명 뿐 아니라 깊이 있는 이론 또는 실증 분석을 제공함으로써 엄밀한 논증에 초점을 두는 학술논문 형태의 연구이며 한국은행 직원 및 한국은행 연구용역사업의 연구 결과물이 수록되고 있습니다.

${ }^{\circledR} \mathrm{BOK}$ 경제연구』는 한국은행 경제연구원 홈페이지(http://imer.bok.or.kr)에서 다운로드하여 보실 수 있습니다.

제2014-1 Network Indicators for Monitoring Intraday Liquidity in BOK-Wire+

2 중소기업에 대한 신용정책 효과

3 경제충격 효과의 산업간 공행성 분석

4 서비스업 발전을 통한 내외수 균형성장: 기대효과 및 리스크

5 Cross-country-heterogeneous and Time-varying Effects of Unconventional Monetary Policies in AEs on Portfolio Inflows to EMEs

6 인터넷뱅킹, 결제성예금 및 은행 수익성과의 관계 분석

7 Dissecting Foreign Bank Lending Behavior During the 2008-2009 Crisis

8 The Impact of Foreign Banks on Monetary Policy Transmission during the Global Financial Crisis of 2008-2009: Evidence from Korea

9 Welfare Cost of Business Cycles in Economies with Individual Consumption Risk

10 Investor Trading Behavior Around the Time of Geopolitical Risk Events: Evidence from South Korea

11 Imported-Inputs Channel of Exchange Rate Pass-Through: Evidence from Korean Firm-Level Pricing Survey
Seungjin Baek

Kimmo Soram ki . Jaeho Yoon

정호성·임호성

황선웅·민성환 ·

신동현 · 김기호

김승원 · 황광명

Kyoungsoo Yoon •

Christophe Hurlin

이동규·전봉걸

Moon Jung Choi •

Eva Gutierrez •

Maria Soledad Martinez Peria

Bang Nam Jeon •

Hosung Lim. Ji Wu

Martin Ellison •

Thomas J. Sargent

Young Han Kim •

Hosung Jung

Jae Bin Ahn -

Chang-Gui Park 


\begin{tabular}{|c|c|c|}
\hline 제2014-12 & 비대칭 금리기간구조에 대한 실증분석 & 김기호 \\
\hline 13 & $\begin{array}{l}\text { The Effects of Globalization } \\
\text { on Macroeconomic Dynamics } \\
\text { in a Trade-Dependent Economy: } \\
\text { the Case of Korea }\end{array}$ & Fabio Milani · Sung Ho Park \\
\hline 14 & $\begin{array}{l}\text { 국제 포트폴리오투자 행태 분석: 채권-주식 } \\
\text { 투자자금간 상호관계를 중심으로 }\end{array}$ & 이주용 · 김근영 \\
\hline 15 & $\begin{array}{l}\text { 북한 경제의 추격 성장 가능성과 } \\
\text { 정책 선택 시나리오 }\end{array}$ & 이근·최지영 \\
\hline 16 & $\begin{array}{l}\text { Mapping Korea's International Linkages } \\
\text { using Generalised Connectedness Measures }\end{array}$ & Hail Park $\cdot$ Yongcheol Shin \\
\hline 17 & $\begin{array}{l}\text { 국제자본이동 하에서 환율신축성과 } \\
\text { 경상수지 조정: 국가패널 분석 }\end{array}$ & 김근영 \\
\hline 18 & $\begin{array}{l}\text { 외국인 투자자가 외환시장과 주식시장 간 } \\
\text { 유동성 동행화에 미치는 영향 }\end{array}$ & 김준한 $\cdot$ 이지은 \\
\hline 19 & $\begin{array}{l}\text { Forecasting the Term Structure } \\
\text { of Government Bond Yields } \\
\text { Using Credit Spreads and Structural Breaks }\end{array}$ & $\begin{array}{l}\text { Azamat Abdymomunov } \\
\text { Kyu Ho Kang } \\
\text { Ki Jeong Kim }\end{array}$ \\
\hline 20 & $\begin{array}{l}\text { Impact of Demographic Change } \\
\text { upon the Sustainability of Fiscal Policy }\end{array}$ & $\begin{array}{l}\text { Younggak Kim· } \\
\text { Myoung Chul Kim } \\
\text { Seongyong Im }\end{array}$ \\
\hline 21 & $\begin{array}{l}\text { The Impact of Population Aging } \\
\text { on the Countercyclical Fiscal Stance in Korea, } \\
\text { with a Focus on the Automatic Stabilizer }\end{array}$ & $\begin{array}{l}\text { Tae-Jeong Kim } \cdot \\
\text { Mihye Lee } \cdot \text { Robert Dekle }\end{array}$ \\
\hline 22 & $\begin{array}{l}\text { 미 연준과 유럽중앙은행의 비전통적 통화정책 } \\
\text { 수행원칙에 관한 고찰 }\end{array}$ & 김병기·김진일 \\
\hline 23 & $\begin{array}{l}\text { 우리나라 일반인의 인플레이션 기대 형성 } \\
\text { 행태 분석 }\end{array}$ & 이한규·최진호 \\
\hline
\end{tabular}


제2014-24 Nonlinearity in Nexus between

Working Hours and Productivity

25 Strategies for Reforming Korea's Labor Market to Foster Growth

26 글로벌 금융위기 이후 성장잠재력 확충: 2014 한국은행 국제컨퍼런스 결과보고서

27 인구구조 변화가 경제성장률에 미치는 영향: 자본이동의 역할에 대한 논의를 중심으로

28 Safe Assets

29 확장된 실업지표를 이용한 우리나라 노동시장에서의 이력현상 분석

Entropy of Global Financial Linkages

31 International Currencies Past, Present and Future: Two Views from Economic History

32 금융체제 이행 및 통합 사례:

남북한 금융통합에 대한 시사점

Measuring Price-Level Uncertainty and Instability in the U.S., 1850-2012

고용보호제도가 노동시장 이원화

및 노동생산성에 미치는 영향

35 해외충격시 외화예금의 역할 : 주요 신흥국 신용스프레드에 미치는 영향을 중심으로 Emerging Market Economies, and Their Policy Responses
Dongyeol Lee

Hyunjoon Lim

Mai Dao · Davide Furceri •

Jisoo Hwang

Meeyeon Kim •

Tae-Jeong Kim

한국은행 경제연구원

손종칠

Robert J. Barro

김현학 · 황광명

Daeyup Lee

Barry Eichengreen

김병연

Timothy Cogley •

Thomas J. Sargent

김승원

정호성 - 우준명

김인수 · 이명수

황광명 - 김경민 -

노충식·김미진

Woon Gyu Choi •

Taesu Kang •

Geun-Young Kim •

Byongju Lee 
제2015-1 글로벌 금융위기 이후 주요국

통화정책 운영체계의 변화

2 미국 장기시장금리 변동이 우리나라 금리기간구조에 미치는 영향 분석 및 정책적 시사점

3 직간접 무역연계성을 통한 해외충격의 우리나라 수출입 파급효과 분석

4 통화정책 효과의 지역적 차이

5 수입중간재의 비용효과를 고려한 환율변동과 수출가격 간의 관계

6 중앙은행의 정책금리 발표가 주식시장 유동성에 미치는 영향

7 은행 건전성지표의 변동요인과 거시건전성 규제의 영향

8 Price Discovery and Foreign Participation in The Republic of Korea's Government Bond Futures and Cash Markets

9 규제가 노동생산성에 미치는 영향:

한국의 산업패널 자료를 이용한 실증분석

10 인구 고령화와 정년연장 연구

(세대 간 중첩모형(OLG)을 이용한 정량 분석)

11 예측조합 및 밀도함수에 의한 소비자물가 상승률 전망

12 인플레이션 동학과 통화정책

13 Failure Risk and the Cross-Section of Hedge Fund Returns

14 Global Liquidity and Commodity Prices

15 Foreign Ownership, Legal System and Stock Market Liquidity
김병기·김인수

강규호·오형석

최문정·김근영

김기호

김경민

이지은

강종구

Jaehun Choi - Hosung Lim •

Rogelio Jr. Mercado •

Cyn-Young Park

이동렬· 최종일·이종한

홍재화 - 강태수

김현학

우준명

Jung-Min Kim

Hyunju Kang •

Bok-Keun $\mathrm{Yu}$.

Jongmin $\mathrm{Yu}$

Jieun Lee $\cdot$ Kee H. Chung 
제2015-16 바젤 II 은행 경기대응완충자본 규제의 기준지표에 대한 연구

17 우리나라 대출 수요와 공급의 변동요인 분석

18 북한 인구구조의 변화 추이와 시사점

19 Entry of Non-financial Firms and Competition in the Retail Payments Market

20 Monetary Policy Regime Change and Regional Inflation Dynamics: Looking through the Lens of Sector-Level Data for Korea

21 Costs of Foreign Capital Flows in Emerging Market Economies: Unexpected Economic Growth and Increased Financial Market Volatility

22 글로벌 금리 정상화와 통화정책 과제: 2015년 한국은행 국제컨퍼런스 결과보고서

23 The Effects of Global Liquidity on Global Imbalances

24 실물경기를 고려한 내재 유동성 측정

25 Deflation and Monetary Policy

26 Macroeconomic Shocks and Dynamics of Labor Markets in Korea

27 Reference Rates and Monetary Policy Effectiveness in Korea

28 Energy Efficiency and Firm Growth

29 An Analysis of Trade Patterns in East Asia and the Effects of the Real Exchange Rate Movements

30 Forecasting Financial Stress Indices in Korea: A Factor Model Approach
서현덕·이정연

강종구 · 임호성

최지영

Jooyong Jun

Chi-Young Choi •

Joo Yong Lee

Roisin O'Sullivan

Kyoungsoo Yoon • Jayoung Kim

한국은행 경제연구원

Marie-Louise DJIGBENOU-KRE •

Hail Park

우준명·이지은

Barry Eichengreen

Tae Bong Kim •

Hangyu Lee

Heung Soon Jung •

Dong Jin Lee .

Tae Hyo Gwon .

Se Jin Yun

Bongseok Choi •

Wooyoung Park.

Bok-Keun Yu

Moon Jung Choi •

Geun-Young Kim • Joo Yong Lee

Hyeongwoo Kim • Hyun Hak Kim. Wen Shi 


\begin{tabular}{|c|c|c|}
\hline 제2016 -1 & $\begin{array}{l}\text { The Spillover Effects of U.S. Monetary } \\
\text { Policy on Emerging Market Economies: } \\
\text { Breaks, Asymmetries and } \\
\text { Fundamentals }\end{array}$ & $\begin{array}{l}\text { Geun-Young Kim } \\
\text { Hail Park } \\
\text { Peter Tillmann }\end{array}$ \\
\hline 2 & $\begin{array}{l}\text { Pass-Through of Imported Input Prices } \\
\text { to Domestic Producer Prices: } \\
\text { Evidence from Sector-Level Data }\end{array}$ & $\begin{array}{l}\text { JaeBin Ahn } \\
\text { Chang-Gui Park } \\
\text { Chanho Park }\end{array}$ \\
\hline 3 & $\begin{array}{l}\text { Spillovers from U.S. Unconventional } \\
\text { Monetary Policy and Its Normalization } \\
\text { to Emerging Markets: A Capital Flow } \\
\text { Perspective }\end{array}$ & $\begin{array}{l}\text { Sangwon Suh } \\
\text { Byung-Soo Koo }\end{array}$ \\
\hline 4 & $\begin{array}{l}\text { Stock Returns and Mutual Fund Flows } \\
\text { in the Korean Financial Market: } \\
\text { A System Approach }\end{array}$ & $\begin{array}{l}\text { Jaebeom Kim } \\
\text { Jung-Min Kim }\end{array}$ \\
\hline 5 & $\begin{array}{l}\text { 정책금리 변동이 성별·세대별 고용률에 } \\
\text { 미치는 영향 }\end{array}$ & 정성엽 \\
\hline 6 & $\begin{array}{l}\text { From Firm-level Imports to Aggregate } \\
\text { Productivity: Evidence from Korean } \\
\text { Manufacturing Firms Data }\end{array}$ & $\begin{array}{l}\text { JaeBin Ahn } \\
\text { Moon Jung Choi }\end{array}$ \\
\hline 7 & $\begin{array}{l}\text { 자유무역협정(FTA)이 한국 기업의 } \\
\text { 기업내 무역에 미친 효과 }\end{array}$ & 전봉걸·김은숙·이주용 \\
\hline 8 & $\begin{array}{l}\text { The Relation Between Monetary and } \\
\text { Macroprudential Policy }\end{array}$ & Jong Ku Kang \\
\hline 9 & $\begin{array}{l}\text { 조세피난처 투자자가 투자 기업 및 주식 } \\
\text { 시장에 미치는 영향 }\end{array}$ & 정호성·김순호 \\
\hline 10 & $\begin{array}{l}\text { 주택실거래 자료를 이용한 주택부문 거시 } \\
\text { 건전성 정책 효과 분석 }\end{array}$ & 정호성·이지은 \\
\hline 11 & $\begin{array}{l}\text { Does Intra-Regional Trade Matter in } \\
\text { Regional Stock Markets?: New } \\
\text { Evidence from Asia-Pacific Region }\end{array}$ & $\begin{array}{l}\text { Sei-Wan Kim } \\
\text { Moon Jung Choi }\end{array}$ \\
\hline 12 & $\begin{array}{l}\text { Liability, Information, and Anti-fraud } \\
\text { Investment in a Layered Retail } \\
\text { Payment Structure }\end{array}$ & $\begin{array}{l}\text { Kyoung-Soo Yoon } \\
\text { Jooyong Jun }\end{array}$ \\
\hline 13 & $\begin{array}{l}\text { Testing the Labor Market Dualism in } \\
\text { Korea }\end{array}$ & $\begin{array}{l}\text { Sungyup Chung } \\
\text { Sunyoung Jung }\end{array}$ \\
\hline 14 & $\begin{array}{l}\text { 북한 이중경제 사회계정행렬 추정을 통한 } \\
\text { 비공식부문 분석 }\end{array}$ & 최지영 \\
\hline
\end{tabular}


제2016-15 Divergent EME Responses to Global and Domestic Monetary Policy Shocks
Woon Gyu Choi ·

Byongju Lee.

Taesu Kang •

Geun-Young Kim 